UDC: 616.831:616.12-008.331.1]-008.63-02-092.9

Yu. M. Kolesnyk, N. V. Kuzo, O. V. Hancheva, A. V. Abramov

\title{
Features of the inducible nitric oxide synthase expression in paraventricular and supraoptic nuclei of hypothalamus in different models of arterial hypertension
}

\author{
Zaporizhzhia State Medical University
}

Key words: Hypothalamus, Experimental Arterial Hypertension, Rats, Magnocellular Neurons, Nitric Oxide Synthase.

The regulation of the paraventricular $(\mathrm{PVN})$ and supraoptic (SON) nuclei's activity is carried out with a great amount of different neurotransmitters, in particular, with nitric oxide. In order to get clear understanding of the local NO effects in hypothalamus in normal condition and different models of hypertension it is necessary to study all isoforms of NOS in PVN and SON.

Our purpose was to find out the features of the inducible nitric oxide synthase (iNOS) expression in magnocellular SON and PVN in SHR and endocrine-saline model of hypertension in rats.

Materials and methods. For all rats the mean blood pressure (mBP) was measured. In Wistar rats mBP was stable during the experiment. In SHR mBP was higher than normal. In animals of the $3^{\text {rd }}$ group with ESM the first measurement (before the modelling) demonstrated normal rates of $\mathrm{mBP}$. Since the $7^{\text {th }}$ day of modelling $\mathrm{mBP}$ started increase and became steadily increased from the $21^{\text {st }}$ day. We obtained the frontal slices of hypothalamus and performed the assessment of iNOS expression using immunofluorescence assay.

The results showed the presence of the constitutive expression of iNOS in the magnocellular neurons of hypothalamus in Wistar rats as well as in both groups of experimental hypertension. The level of iNOS expression in magnocellular nuclei was dependent both on type of hypertension and topography of magnocellular neurons in hypothalamus. In SHR there was high expression of iNOS in PVN and low one in SON, whereas in endocrine-saline model there was high expression in SON and there were no substantial changes of the iNOS expression in PVN.

Conclusions. We believe the alteration of iNOS expression in magnocellular nuclei of hypothalamus could participate in development and/or adaptation to hypertension.

Особливості експресії індуцибельної синтази оксиду азоту в паравентрикулярному та супраоптичному ядрах гіпоталамуса при різних моделях артеріальної гіпертензії

Ю. М. Колесник, Н. В. Кузьо, О. В. Ганчева, А. В. Абрамов

Регуляція активності супраоптичного (СОЯ) та паравентрикулярного (ПВЯ) ядер здійснюється внаслідок великої кількості нейротрансміттерів, зокрема оксиду азоту (NO). Вважаємо, що для отримання чіткого розуміння локальних ефектів NO в гіпоталамусі необхідно дослідити експресію всіх ізоформ синтази оксиду азоту в ПВЯ та СОЯ.

Мета роботи - встановлення особливостей експресії індуцибельної синтази оксиду азоту (iNOS) у великоклітинних СОЯ та ПВЯ гіпоталамуса в SHR і за умов ендокринно-сольової моделі (ECM) артеріальної гіпертензії в щурів.

Матеріали та методи. Усім щурам виміряли середній артеріальний тиск (сAT). У щурів лінії Wistar сAТ був стабільним протягом експерименту. У щурів лінії SHR сAT був стабільно підвищений. У щурів ЕСМ до початку моделювання сАТ був нормальним. 37 доби моделювання сАТ підвищувався та став стабільно підвищеним, починаючи з 21 доби моделювання. Отримали фронтальні зрізи гіпоталамуса та виконали оцінювання експресії iNOS у них за допомогою імунофлуоресцентного аналізу.

Результати. Дослідження показало наявність конституційної експресії iNOS у великоклітинних нейронах гіпоталамуса як у щурів лінії Wistar, так і в обох експериментальних моделях. Рівень експресії iNOS у великоклітинних нейронах залежав як від типу моделі, так і від топографічної приналежності великоклітинних нейронів. Так, у SHR високий рівень експресії iNOS був відзначений у ПВЯ, тоді як у СОЯ він був значно нижчим за показники контрольної групи. 3 іншого боку, за умов ендокринно-сольової моделі значне збільшення експресії іNOS відзначалося в СOЯ, тоді як у ПВЯ ми не знайшли вірогідних змін.

Висновки. Зміна рівня експресії iNOS у великоклітинних нейронах гіпоталамуса може брати участь у розвитку та/або адаптації до артеріальної гіпертензії.

Ключові слова: гіпоталамус, експериментальна артеріальна гіпертензія, щури, великоклітинні нейрони, синтаза оксиду азоту.

Запорізький медичний журнал. - 2016. - № 4 (97). - С. 4-10

\section{Особенности экспрессии индуцибельной синтазы оксида азота в паравентрикулярном и супраоптическом} ядрах гипоталамуса при разных моделях артериальной гипертензии

Ю. М. Колесник, Н. В. Кузьо, О. В. Ганчева, А. В. Абрамов

Регуляция активности супраоптического (СОЯ) и паравентрикулярного (ПВЯ) ядер гипоталамуса осуществляется благодаря большому количеству нейротрансмиттеров, в частности, оксиду азота (NO). Мы считаем, что для получения чёткого понимания локальных эффектов NO необходимо изучить экспрессию всех изоформ синтазы оксида азота в ПВЯ и СОЯ.

Цель работы - установление особенностей экспрессии индуцибельной синтазы оксида азота (iNOS) в крупноклеточных COЯ и ПВЯ гипоталамуса у SHR и в условиях эндокринно-солевой модели (ЭСM) артериальной гипертензии у крыс.

Материалы и методы. Всем крысам было измерено среднее артериальное давление (сAД). У крыс линии Wistar сAД было стабильное на протяжении всего эксперимента. У крыс линии SHR сAД было стабильно повышенным. У крыс ЭСМ до начала эксперимента сАД было нормальным. С 7 суток моделирования сАД начало повышаться и стало стабильно повышенным, начиная с 21 суток моделирования. Мы получили фронтальные срезы гипоталамуса и провели оценку экспрессии iNOS в них с помощью иммунофлуоресцентного анализа.

Результаты. Исследование показало наличие конституциональной экспрессии iNOS в крупноклеточных нейронах гипоталамуса как у крыс линии Wistar, так и в обеих моделях экспериментальной гипертензии. Уровень экспрессии iNOS в крупноклеточных нейронах зависел как от типа модели, так и от топографической принадлежности крупноклеточных нейронов. Так, у SHR высокий уровень экспрессии iNOS отмечался в ПВЯ, в то время как в СОЯ он был значительно ниже показателей контрольной группы. С другой стороны, 
в условиях эндокринно-солевой модели значительное увеличение экспрессии iNOS отмечалось в СOЯ, в то время как в ПВЯ мы не выявили достоверных отличий.

Выводы. Изменение уровня экспрессии iNOS в крупноклеточных нейронах гипоталамуса может принимать участие в развитии и/или адаптации к артериальной гипертензии.

Ключевые слова: гипоталамус, экспериментальная артериальная гипертензия, крысы, крупноклеточные нейроны, синтаза оксида азота.

Запорожский медицинский жсурнал. - 2016. - № 4 (97). - С. 4-10

$\mathrm{T}$ he blood pressure (BP) regulation involves several regulatory systems on different levels. It is realized through neurogenic and hormonal mechanisms and local mediators' systems.

The major integrative centre of the cardiovascular regulation is hypothalamus. It is considered to be as a key component of neuronal circuits of central blood pressure control. It provides coordination and integration of signals in response to central and peripheral stimuli. From the standpoint of BP regulation its paraventricular $(\mathrm{PVN})$ and supraoptic $(\mathrm{SON})$ nuclei are the most interesting.

The hypothalamic control systems implement their regulation of vascular tone both through the influence on sympathetic nervous centres and via the involvement of hormones of neuro- and adenohypophysis. The regulation of PVN and SON activity is carried out with a great amount of different neurotransmitters [1], with the nitric oxide among them (NO) $[2,3]$.

The local nitric oxide mediator system implements its effects via paracrine action both on the peripheral vascular resistance and on the centres in the brain, where it carries out the trophic and neurotransmitter's functions. This system takes part in a list of physiological processes, such as gene transcription, translation and posttranslational modification of proteins, vasodilation, apoptosis induction and neuromuscular transmission of signals [4]. It also promotes a linkage and integration of the hypothalamic structures with different regions of the brain [5].

In mammals NO generates via three isoforms of the nitric oxide synthase (NOS). They are defined as neuronal (nNOS), inducible (iNOS) and endothelial (eNOS). It was previously thought nNOS and eNOS express constitutively, while iNOS appears only during immune response [6]. Nevertheless, all isoforms were found in the brain where they serve as the modulators of different centres through the NO synthesis, in particular, the sympathetic centres of autonomic nervous system [4].

The immunohistochemical staining of the nNOS showed it was present in great number of neurons in PVN with prevailing in magnocellular subnuclei compared with parvocellular $[7,8]$. nNOS also was found in 6-10\% of neurons with spinal projections [8-10] and in 12-25\% neurons with projection into the rostral ventrolateral medulla (RVLM) [11-13]. Nevertheless, there is an opinion that the magnocellular neurosecretory neurons are the main source of nitric oxide in PVN [7,14]. Current data show the involvement of $\mathrm{NO}$ derived from the magnocellular neurons in the modulation of autonomic outflow from PVN [7]. It was based on the fact of interaction of magnocellular neuron bodies and dendrites with spinal projections of parvocellular neurons of PVN $[7,8]$. Therefore, NO derived from magnocellular neurons could influence on the activity of the presympathetic neurons.

For a long time, the iNOS was considered to be a source of NO during the pathological processes, however in increasing number of studies the constitutive iNOS expression and its physiological role are discussed. The constitutive expression of iNOS was found in neurons, microglia and astrocytes. $[15,16]$. Another research group found the high concentrations of iNOS in cortex and forebrain during embryonal and early postnatal life stages, and during the later stages iNOS activity falls to barely noticeable values [17].

It is also known the NO regulates the sympathetic tone not only in normal conditions, but during different diseases. Its role is significant in the development and maintenance of such pathological states as neurodegenerative diseases, chronic renal and heart failure and hypertension [18].

Considering the fact, the NO generation involves three isoforms, in order to get correct understanding of the local NO effects in hypothalamus during normal condition and different models of hypertension it is necessary to study all isoforms of NOS in PVN and SON.

Earlier in out studies we found that both in SHR and endocrine-saline model (ESM) of hypertension there was a significant increase of the nNOS expression both in SON and PVN. In addition, eNOS expression was dependent on origin of hypertension and the functional role of nuclei [19].

In present study our purpose was to find out the features of the iNOS expression in magnocellular supraoptic and paraventricular nuclei of hypothalamus in SHR and endocrine-saline model of hypertension in rats.

\section{Material and methods \\ Animals and treatment}

Experiment was carried out in accordance with the Council Directive 2010/63EU of the European Parliament and of the Council of 22 September 2010 on the protection of animals used for scientific purposes and with national "General ethic principles of the animal experiments" (Ukraine, 2001). The carrying out of this experiment was approved by the Commission on Bioethics of Zaporizhzhia State Medical University.

Experimental groups consisted of 20 mature male Wistar rats and 10 mature SHR in age of 5-6 month with body weight of 250-270 g, which were treated in common laboratory conditions (12-hour light cycle, $\mathrm{T}=+22 \%$ ) with free access to water and food. Animals were obtained from the experimental-biological clinic "Biomodelservice", Kyiv, Ukraine. Rodents were allocated into 3 experimental groups: the $1^{\text {st }}$ group consisted of 10 Wistar rats and was used as a control group; the $2^{\text {nd }}$ group consisted of 10 SHR; the $3^{\text {rd }}$ group consisted of 10 Wistar rats, which underwent the endocrine-saline modelling of hypertension [20]. For creating ESM during 30 days rats were treated with prednisolone intramuscularly at 7 o'clock with dose of $2 \mathrm{mg} / \mathrm{kg}$ and in 20 o'clock with dose of $4 \mathrm{mg} / \mathrm{kg}$ with simultaneous watering with $5 \mathrm{ml}$ of saline $(\mathrm{NaCl} 2.3 \%)$.

For all rats the mean blood pressure (mBP) was measured with the non-invasive system BP-2000 (Visitech Systems, USA). First 
measurement was done a day before experiment beginning and then on the $1^{\text {st }}, 7^{\text {th }}, 14^{\text {th }}, 21^{\text {st }}$ and $30^{\text {th }}$ day of the experiment. The $\mathrm{mBP}$ measurement procedure was carried out in accordance with the protocol recommended by manufacturer: measurement was carried out in silence with exclusion of loud noises and human voice; animals were accustomed to the restrainer during 5 days before the procedure; for each measurement different restrainers were used; in the day of measurement animals were preheated in restrainers, then 10 preliminary and 10 control measurements were performed; animals were in restrainer no more than 30 minutes each time.

In control group $\mathrm{mBP}$ was stable $(83.75 \pm 0.96 \mathrm{~mm} \mathrm{Hg})$ during the experiment. In rats of the $2^{\text {nd }}$ group $\mathrm{mBP}$ was higher than normal $(125.78 \pm 1.12 \mathrm{~mm} \mathrm{Hg})$. In animals of the $3^{\text {rd }}$ group with ESM the first measurement (before the modelling) demonstrated normal rates of $\mathrm{mBP}$. Since the $7^{\text {th }}$ day of modelling $\mathrm{mBP}$ started increase and became steadily increased from the $21^{\text {st }}$ day $(137.77 \pm 1.23 \mathrm{~mm} \mathrm{Hg})$. Data about distribution of $\mathrm{mBP}$ in experimental groups stated in Fig. 1.

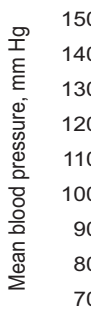

$$
\begin{array}{r}
150 \\
140 \\
130 \\
120 \\
110 \\
100 \\
90 \\
80 \\
70
\end{array}
$$
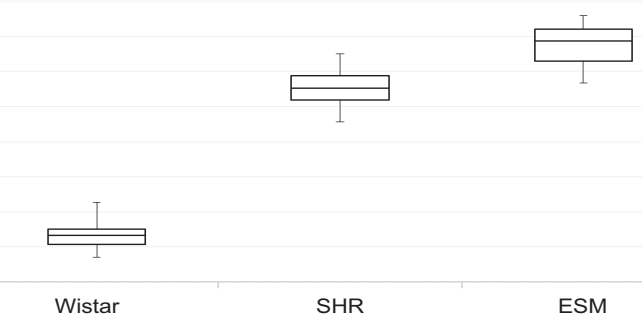

Fig. 1. This box-and-whisker plot shows levels of mean blood pressure in Wistar $(\mathrm{n}=10), \operatorname{SHR}(\mathrm{n}=10)$ and $\operatorname{ESM}(\mathrm{n}=10)$ experimental groups. For ESM group we indicated the mean of blood pressure from 21 day of the modelling. Data presented as min and max, the $1^{\text {st }}$ and the $3^{\text {rd }}$ quartiles and median.

\section{Tissue processing}

On the last day of the experiment after the 16 hours of starvation rats were anesthetized with $40 \mathrm{mg} / \mathrm{kg}$ of thiopentone intraperitoneally and infused with the warm $(\mathrm{T}=+37 \%)$ Bueno fixator in the descending aorta. Then animals were decapitated. Brain was immediately extracted and washed with $0.9 \%$ saline $(\mathrm{T}=+4 \%)$ and then placed into Bueno fixator for 20 hours in room temperature. After 2-hour washing of picric acid in running cold water the brain was dehydrated in ascending concentrations of ethanol (from $50 \%$ to $100 \%$ ), ethanol $100 \%$ + chloroform (in ratio 2:1, 1:1, 1:2), chloroform, chloroform + paraplast (MkCormick, USA) in ratio $1: 3\left(\mathrm{~T}=+37^{\circ} \mathrm{C}\right)$, paraplast $(\mathrm{T}=+56 \%, 1$ hour) and then imbedded into paraplast blocks. In accordance with the stereotaxic atlas [21] on rotational microtome Microm-325 (Microm Corp., Germany) the serial frontal slices of hypothalamus of $14 \mu \mathrm{m}$ were prepared. These slices were incubated in thermostat for 7 days $(\mathrm{T}=+37 \%)$. Then paraplast was dissolved in orto-xylole (100\%) during $10 \mathrm{mi}-$ nutes, the slices were rehydrated in descending concentrations of ethanol (100\% to $50 \%$ ) The ethanol remnants washed with PBS ( $\mathrm{pH}=7.2)$ during 5 minutes triply.

\section{Immunostaining}

With aim to identify the iNOS, histological slices were incubated with mouse IgG to iNOS, conjugated with FITC (sc-7271
FITC, Santa Cruz Biotechnology, USA) in dilution ratio 1:200. Slides with slices and applied antibodies were placed in polymeric containers into refrigerator $\left(\mathrm{T}=+4^{\circ} \mathrm{C}\right)$ for 24 hours. Then antibodies were washed out with PBS during 5 minutes triply and slides were covered in glycerol/PBS solution (ratio 9:1).

Negative control

For a negative control of the specificity we took several slides and incubated them with blocking peptide (sc-7271 ${ }^{\circ} \mathrm{P}$, Santa Cruz Biotechnology, USA) in dilution ratio 1:50, then slides were processed as stated above. In this slides there was no significant fluorescence observed.

\section{Immunofluorescence assay}

We performed the assessment of slides with iNOS immunostaining in ultraviolet excitation spectrum with the wave length of $390 \mathrm{~nm}$ using light filter with high emission 38HE (Carl Zeiss), microscope AxioScope (Carl Zeiss), immersion lens F-Fluar 40x/1.30 Oil (Carl Zeiss) and immersion oil Immersol 518F (Carl Zeiss). All images were obtained with 8-bit camera AxioCam-ERc 5s (Carl Zeiss) and written as a computer file in TIFF format with resolution 2560x1920 in application AxioVision 4.8 LE (Carl Zeiss). All images were done with the same brightness, exposition and correction settings. Image analysis was performed in ImageJ (NIH, USA). Before analysis the microscope scaling was taken in attention with aim to convert pixels to $\mu \mathrm{m}^{2}$. During the analysis in interactive mode we defined the regions of interest (ROI) with the significant fluorescence. In ROI we calculated both the absolute area $\left(\mu \mathrm{m}^{2}\right)$ of ROI and the immunoreactive material (IRM) and corrected total fluorescence (CTF, Uif), which is directly proportional to the contain of IRM [33]. With aim of integrative assessment, we calculated the IRM specific area (SA, \%) as absolute area of IRM divided by absolute area of ROI and IRM concentration (CONC, $\mathrm{mU}_{\text {if }} / \mu \mathrm{m}^{2}$ ) as CTF divided by absolute area of ROI. We evaluated non less than 100 vision fields in each group.

\section{Statistical analysis}

All statistical calculations were done in Microsoft Excel 2016 (Microsoft Corp.) with Attestat 12. We calculated the mean (M) and standard mean error $(\mathrm{m})$ for each of the indexes. With aim to find the significance of the differences in experimental groups we used ANOVA, post hoc $t$-tests with Holm-Bonferroni correction were performed and probability of differences was defined using Student's distribution table. Significant difference was considered for $P<0.05$.

\section{Results}

During the visual analysis of the hypothalamic slices we have found that the IRM to iNOS in SON (Fig. 2) and PVN (Fig. 3) in rats of all groups was allocated in cytoplasm of magnocellular neurons diffusely and in granules.

The obtained results are listed in Table 1 and Fig. 4.

\section{Discussion}

The presence of the iNOS expression in magnocellular nuclei of hypothalamus in the $1^{\text {st }}$ group proves the basal expression of this NOS isoform. This fact allows us to suggest the physiological role of iNOS and its constitutive expression.

The obtained results are consistent with modern conception of the physiological role of iNOS in central nervous system. Buskila with colleagues [22] showed the existence of the iNOS-mediated NO-secreting neurons and their activity in 


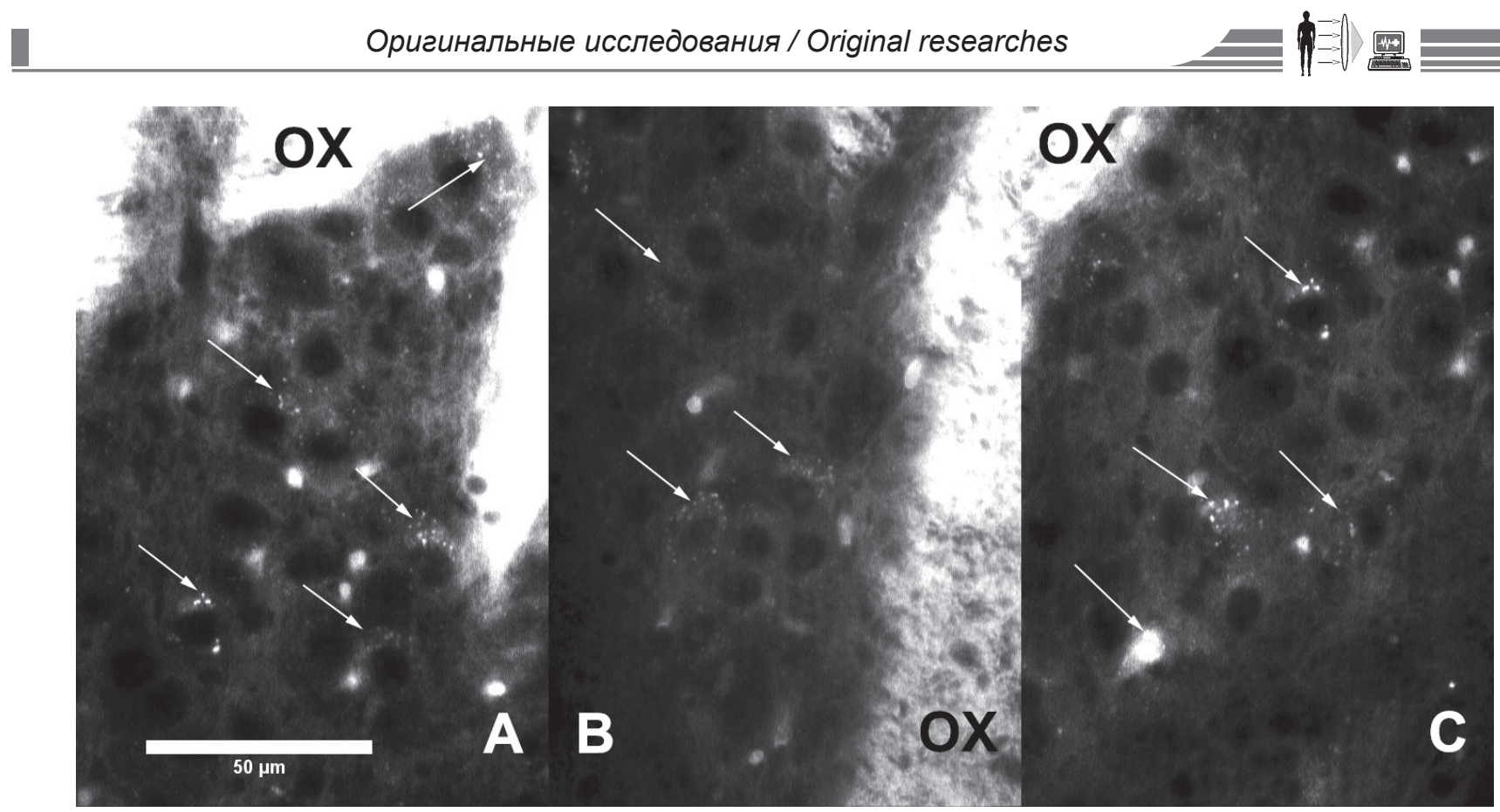

Fig. 2. This image shows the allocation of IRM to iNOS in SON of Wistar (A), SHR (B) and ESM (C). Indirect immunofluorescense. 400x. Arrows mark IRM granules. OX states for optic chiasm.

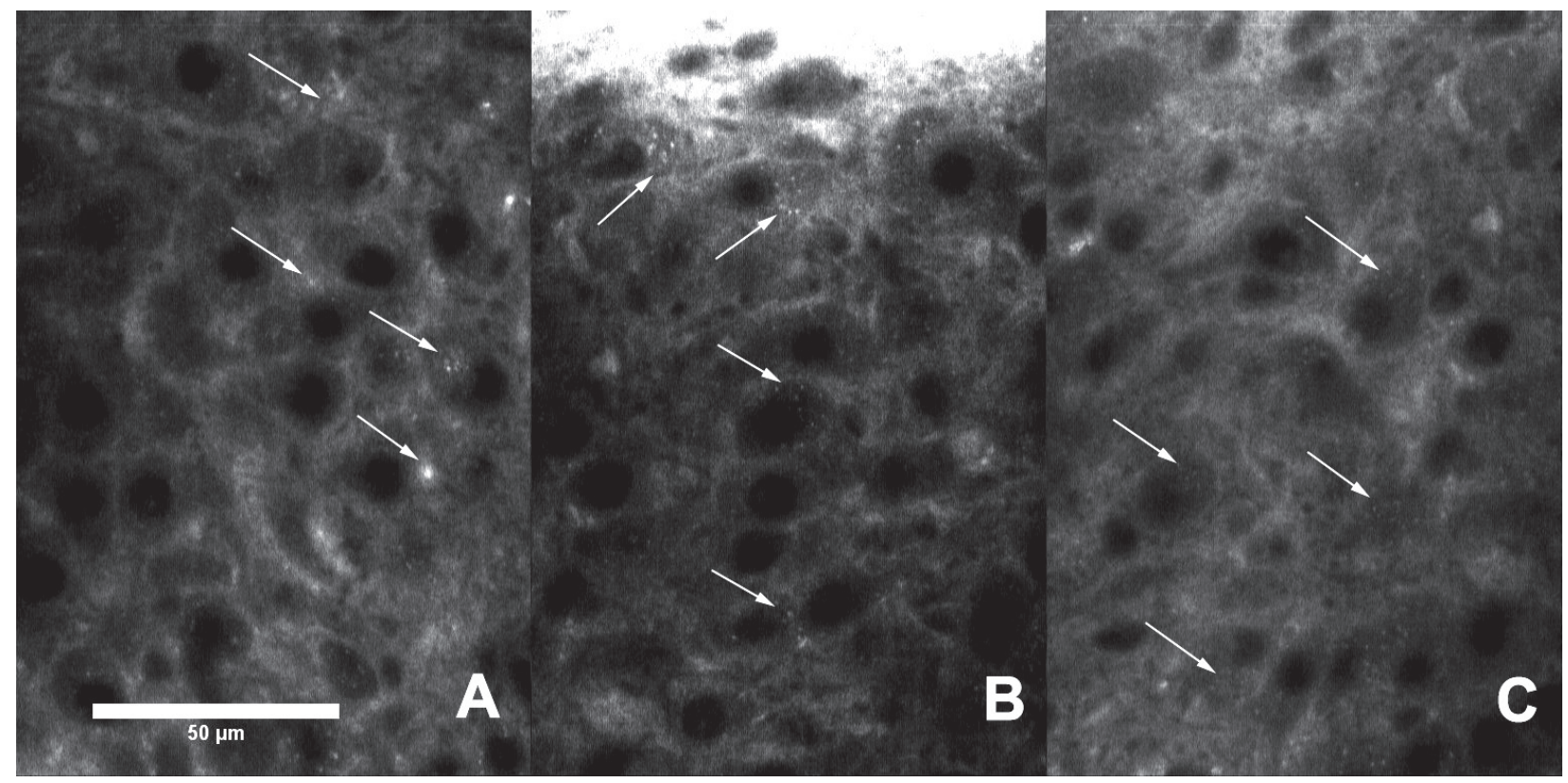

Fig. 3. This image shows the allocation of IRM to iNOS in magnocellular PVN of Wistar (A), SHR (B) and ESM (C). Indirect immunofluorescense. 400x. Arrows mark IRM granules.

Table 1

Indexes of the iNOS expression in magnocellular neurons of SON and PVN in Wistar, SHR and ESM rats.

\begin{tabular}{|c|c|c|c|c|c|c|}
\hline & \multicolumn{3}{|c|}{ SON } & \multicolumn{2}{c|}{ PVN } \\
\hline $\begin{array}{c}\text { Groups, } \\
\mathrm{n}=10\end{array}$ & $\mathrm{CTF}, \mathrm{U}_{\text {if }}$ & $\mathrm{CONC}, \mathrm{mU}_{\mathrm{if}} / \mu \mathrm{m}^{2}$ & $\mathrm{SA}, \%$ & CTF, $\mathrm{U}_{\text {if }}$ & CONC, $\mathrm{mU}_{\text {if }} / \mu \mathrm{m}^{2}$ & SA, \% \\
\hline Wistar & $111.69 \pm 4.92$ & $11.56 \pm 0.42$ & $33.27 \pm 0.8$ & $71.56 \pm 5.22$ & $7.05 \pm 0.3$ & $44.82 \pm 0.99$ \\
\hline SHR & $131.14 \pm 3.12^{1}$ & $9.85 \pm 0.24^{1}$ & $38.08 \pm 0.85^{1}$ & $157.94 \pm 4.8^{1}$ & $11.84 \pm 0.24^{1}$ & $56.62 \pm 0.9^{1}$ \\
\hline ESM & $202.08 \pm 7.57^{1.2}$ & $16.53 \pm 0.65^{1.2}$ & $36.71 \pm 0.86^{1}$ & $69.5 \pm 2.27^{2}$ & $6.85 \pm 0.09^{2}$ & $48.63 \pm 0.52^{1.2}$ \\
\hline
\end{tabular}

Notes: Data presented as mean \pm standard error of the mean, $\left({ }^{1}\right)$ is significant difference $(P<0.05)$ compared with Wistar, $\left({ }^{2}\right)$ is significant difference $(P<0.05)$ compared with SHR. 

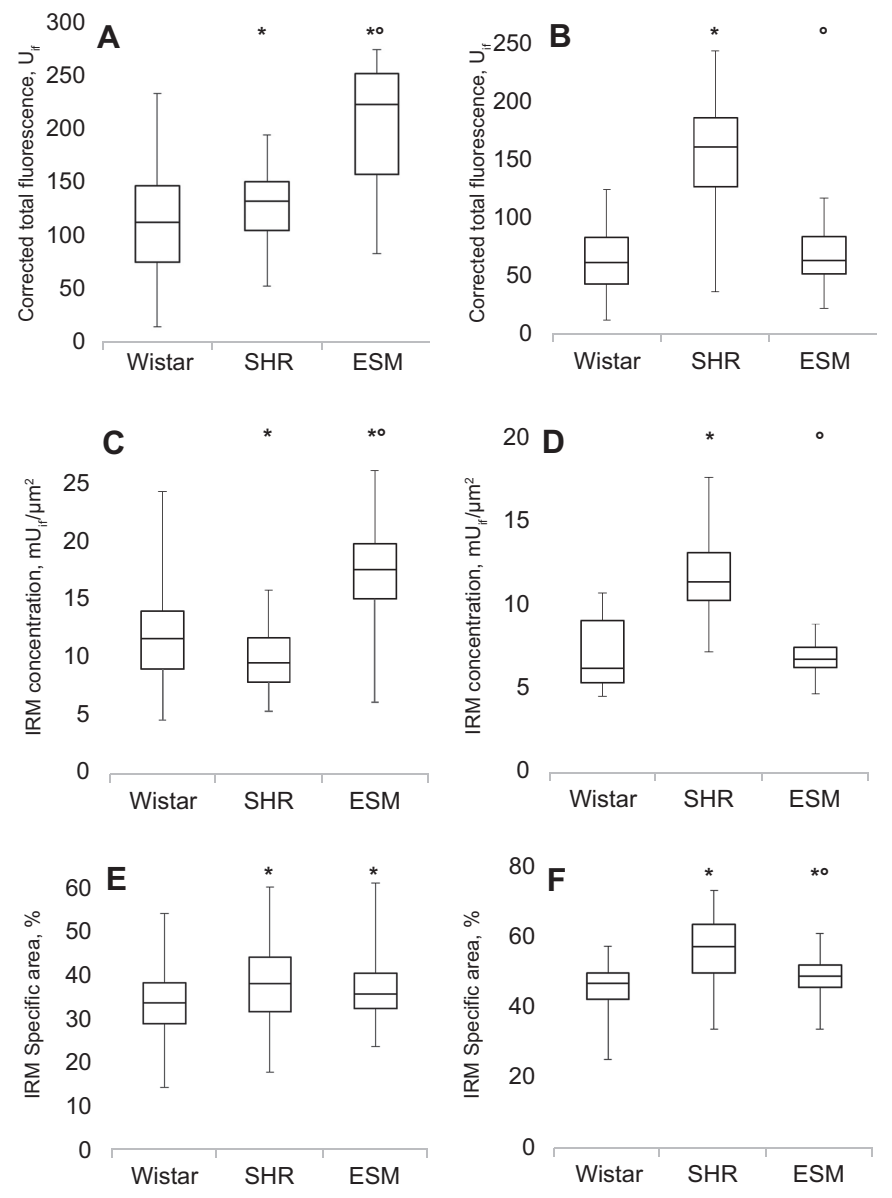

Fig. 4. These box-and-whisker plots show a distribution of CTF, CONC and SA in SON (A,C,E) and PVN (B,D,F), respectively, in Wistar (control, $n=10)$, SHR $(n=10)$ and ESM $(n=10)$ rats. Data presented as min and max, 1st and 3rd quartiles and median, $(*)$ is significant difference $(\mathrm{P}<0,05)$ compared with Wistar, $\left(^{\circ}\right)$ is significant difference $(\mathrm{P}<0.05)$ compared with SHR.

murine neocortex and amygdala. During the experiment with surviving brain slices they observed the change in intensity of the iNOS fluorescence related to the presence of different inhibitors. Also these scientists found iNOS provides at least $10 \%$ of general NOS activity in the brain [23]. In another experiment they found the iNOS-dependent NO-mediated derivatives take part in presynaptic potentiation in the posterior horn. Also investigators found iNOS-dependent modulation of the neurotransmitters release, in particular, glutamate [23].

Furthermore, our results about the iNOS expression in magnocellular nuclei of hypothalamus are consistent with data about expression of iNOS both in magnocellular neurons and glial cells [24]. This substantiates our suggestion about the constitutive role of iNOS the central nervous system activity, in particular, of hypothalamus.

From the other side, we have found the features of the iNOS expression, which are dependent both on the origin of the hypertension and topography of magnocellular neurons of hypothalamus. In SHR the significant increase of iNOS expression (CTF, CONC and SA) was found in magnocellular part of PVN, whereas in SON we have not found significant changes of its expression except SA. In contrast, in endocrine-saline hypertension there was observed the increase of iNOS expression in
SON (CTF, CONC and SA) with decrease of its CONC in PVN despite of increase of CTF and SA.

We believe that the differences of iNOS expression, we have identified, are dependent on the specific role of the nuclei in central control of BP.

It is known that PVN has both direct influence on sympathetic centres of the spinal cord and indirect one on them via RVLM [13]. Thus, under the influence of PVN the adaptive changes of the vasomotor centres run accordingly to changes of the external and internal environment. Chinese scientists have found the local inhibition of neuronal and iNOS in RVLM leads to the changes in sympathetic tone with significant cardiovascular haemodynamic effects $[25,26]$. Also they found the selective inhibition of nNOS or iNOS in RVLM leads to controversial haemodynamic effects. This proves the simultaneous expression of nNOS and iNOS but their different influence on the medullar centres of blood pressure BP regulation. Presence of constitutive iNOS expression in RVLM was also proved by expression of the respective mRNA in normal conditions, and its amount was about $20 \%$ of the nNOS mRNA [27].

According to another data the hyperexpression of iNOS in the brain leads to increase of central sympathetic outflow [28]. This shows the similar to nNOS effects in influence on cardiovascular activity mediated through RVLM [15]. It is interesting that eNOS shows the opposite effects. The eNOS activity in RVLM leads to decrease of mean blood pressure, heart rate and expression of noradrenaline with urine, which indicates the sympatholytic activity of eNOS [28].

It is well known that the main function of SON is the water-salt balance regulation and the control of blood volume. The role of iNOS in pathogenesis of salt models of hypertension was shown in different organs including heart [29] and kidneys [30-32]. According to results of our research the significant increase of the iNOS expression was found in SON nuclei in rats with endocrine-saline model. Probably, this fact may be explained by the key role of this nucleus in adaptation to high BP or in violations of $\mathrm{BP}$ regulation mechanisms.

\section{Conclusions}

Thus, the results of current study showed demonstrated the presence of the constitutive expression of iNOS in the magnocellular neurons of hypothalamus in Wistar rats with normal blood pressure. In the experimental hypertension the level of iNOS expression in magnocellular nuclei was dependent both on the origin and topography of magnocellular neurons in hypothalamus. The controversial features of iNOS expression were found in SHR and ESM rats: in SHR there we found high expression of iNOS in PVN and low one in SON, whereas in ESM there was the high iNOS expression found in SON, and there were no substantial changes of the iNOS expression in PVN. We believe the alteration of iNOS expression in magnocellular nuclei of hypothalamus could participate in development and/or adaptation to hypertension.

Conflicts of Interest: authors have no conflict of interest to declare.

\section{Authors contribution}

Kolesnyk Yu. M.; supervision, made critical revision of the manuscript for key intellectual content, final approval of the version to be published. Kuzo N. V.: conceived and designed 
the research; acquired and processed the data; performed statistical analysis; drafted the manuscript; made critical revision of the manuscript for key intellectual content. Gancheva O. V.: conceived and designed the research, made critical revision of the manuscript for key intellectual content. Abramov A. V.: acquired and processed the data; made critical revision of the manuscript for key intellectual content.

\section{Abbreviations}

$\mathrm{BP}$, blood pressure; CONC, concentration of IRM; CTF, corrected total fluorescence; eNOS, endothelial nitric oxide synthase; ESM, endocrine-saline model; IRM, immunoreactive material; iNOS, inducible nitric oxide synthase; $\mathrm{mBP}$, mean blood pressure; nNOS neuronal nitric oxide synthase; NO, nitric oxide; NOS, nitric oxide synthase; PVN, paraventricular nucleus; ROI, region of interest; RVLM, rostral ventrolateral medulla; SA, specific area of IRM; SON, supraoptic nucleus.

\section{Acknowledgements}

The authors are grateful to associate professor Olga V. Melnikova for assistance in translation of this article.

\section{References}

1. Sawchenko, P. \& Swanson, L. (1982). Immunohistochemical identification of neurons in the paraventricular nucleus of the hypothalamus that project to the medulla or to the spinal cord in the rat. The Journal Of Comparative Neurology, 205(3), 260-272. doi: 10.1002/cne.902050306.

2. Ventura, R., Aguiar, J., Antunes-Rodrigues, J., \& Varanda, W. (2008). Nitric oxide modulates the firing rate of the rat supraoptic magnocellular neurons. Neuroscience, 155(2), 359-365. doi: 10.1016/j.neuroscience.

3. Yamova, L., Dmitriy, A., Glazova, M., Chernigovskaya, E., \& Huang, P. (2007). Role of neuronal nitric oxide in the regulation of vasopressin expression and release in response to inhibition of catecholamine synthesis and dehydration. Neuroscience Letters, 426(3), 160-165. doi: 10.1016/j.neulet.2007.08.066.

4. Forstermann, U. \& Sessa, W. (2012). Nitric oxide synthases: regulation and function. European Heart Journal, 33(7), 829-837. doi: 10.1093/eurheartj/ehr304.

5. Hardingham, N., Dachtler, J., \& Fox, K. (2013). The role of nitric oxide in pre-synaptic plasticity and homeostasis. Frontiers In Cellular Neuroscience, 7. doi: 10.3389/fncel.2013.00190.

6. Brown, G. \& Neher, J. (2010). Inflammatory Neurodegeneration and Mechanisms of Microglial Killing of Neurons. Molecular Neurobiology, 41(2-3), 242-247. doi: 10.1007/s12035-010-8105-9.

7. Stern, J. (2004). Nitric oxide and homeostatic control: an intercellular signalling molecule contributing to autonomic and neuroendocrine integration? Progress In Biophysics And Molecular Biology, 84(2-3), 197-215. http://dx.doi.org/10.1016/j.pbiomolbio.2003.11.015

8. Watkins, N., Cork, S., \& Pyner, S. (2009). An immunohistochemical investigation of the relationship between neuronal nitric oxide synthase, GABA and presympathetic paraventricular neurons in the hypothalamus. Neuroscience, 159(3), 1079-1088. doi: 10.1016/j. neuroscience.2009.01.012.

9. Weiss, M. L., Chowdhury, S. I., Patel, K. P., Kenney, M. J. \& Huang, J. (2001). Neural circuitry of the kidney: NO-containing neurons. Brain Res. 919, 269-282. doi: 10.1016/S00068993(01)03030-X.

10. Li, D.-P., Chen, S.-R. \& Pan, H.-L. (2002). Nitric oxide inhibits spinally projecting paraventricular neurons through potentiation of presynaptic GABA release. J. Neurophysiol. 88, 2664-2674. doi: 10.1152/jn.00540.2002.

11. Li, Y., Zhang, W., \& Stern, Z. (2003). Nitric oxide inhibits the firing activity of hypothalamic paraventricular neurons that innervate the medulla oblongata: role of GABA. Neuroscience, 118, 585-601. doi: 10.1016/S0306-4522(03)00042-3.

12. Kantzides, A. \& Badoer, E. (2005). nNOS-containing neurons in the hypothalamus and medulla project to the RVLM. Brain Res., 1037, 25-34. doi: 10.1016/j.brainres.2004.11.032.

13. Pyner, S. \& Coote, J. H. (1999) Identification of an efferent projection from the paraventricular nucleus of the hypothalamus terminating close to spinally projecting rostral ventrolateral medullary neurons. Neuroscience, 88, 949-957. doi: 10.1016/ S0306-4522(98)00255-3.

14. Nyle'n, A., Skagerberg, G., Alm, P., Larsson, B., Holmqvist, B. \& Andersson, K. E. (2001). Nitric oxide synthase in the hypothalamic paraventricular nucleus of the female rat: organisation of spinal projections and coexistence with oxytocin or vasopressin. Brain Res., 908, 10-24. http://dx.doi.org/10.1016/ S0006-8993(01)02539-2.

15. Villanueva, C. \& Giulivi, C. (2010). Subcellular and cellular locations of nitric oxide synthase isoforms as determinants of health and disease. Free Radical Biology And Medicine, 49(3), 307-316. doi: 10.1016/j.freeradbiomed.2010.04.004.

16. Amitai, Y. (2010). Physiologic role for "inducible" nitric oxide synthase: A new form of astrocytic-neuronal interface. Glia, 58(15), 1775-1781. doi: 10.1002/glia.21057.

17. Koh, P. (2012). Ferulic acid modulates nitric oxide synthase expression in focal cerebral ischemia. Laboratory Animal Research, 28(4), 273. doi: 10.5625/lar.2012.28.4.273.

18. Wang, Y. \& Golledge, J. (2012). Neuronal Nitric Oxide Synthase and Sympathetic Nerve Activity in Neurovascular and Metabolic Systems. CNR, 10(1), 81-89. doi: 10.2174/156720213804805963.

19. Kolesnyk, Y. M., Hancheva, O. V., \& Kuzo, N. V. (2015). Osoblyvosti ekspresii konstytutyvnykh izoform syntazy oksydu azotu $\mathrm{v}$ paraventrykuliarnomu ta supraoptychnomu yadrakh hipotalamusa pry arterialnii hipertenzii riznoho henezu. [The features of expression of constitutive isoforms of the nitric oxide synthase in paraventricular and supraoptic nuclei of the hypothalamus in hypertension of different origins]. Pathologia, 3(35), 21-25. [in Ukrainian]. doi: 10.14739/2310-1237.2015.3.56310.

20. Kolesnyk, Yu. M., Hancheva, O. V., Abramov, A. V., Ivanenko, T. V., Tishchenko, S. V., \& Kuzo, N. V. (patentee) (2015) Patent Ukrainy №u 201503152 Sposib modeliuvannia symptomatychnoi arterialnoi hipertenzii u dribnykh hryzuniv [Patent of Ukraine №u 201503152 Method of Modeling of Symptomatic Hypertension in Rodents]. Biuleten, 20 [in Ukrainian]

21. Paxinos, G. \& Watson, C. (2007). The rat brain in stereotaxic coordinates. Amsterdam: Elsevier.

22. Buskila, Y., Abu-Ghanem, Y., Levi, Y., Moran, A., Grauer, E., \& Amitai, Y. (2007). Enhanced Astrocytic Nitric Oxide Production and Neuronal Modifications in the Neocortex of a NOS2 Mutant Mouse. Plos ONE, 2(9), e843. doi: 10.1371/journal. pone. 0000843

23. Buskila, Y. \& Amitai, Y. (2010). Astrocytic iNOS-Dependent Enhancement of Synaptic Release in Mouse Neocortex. Journal Of Neurophysiology, 103(3), 1322-1328. doi: 10.1152/jn.00676.2009.

24. Grange-Messent, V., Raison, D., Dugas, B., \& Calas, A. (2004). Noradrenaline up-regulates the neuronal and the inducible nitric oxide synthase isoforms in magnocellular neurons of rat brain slices. J. Neurosci. Res., 78(5), 683-690. doi: 10.1002/ jnr.20331.

25. Chan, S., Wang, L., \& Chan, J. (2003). Differential engagements of glutamate and GABA receptors in cardiovascular actions of endogenous nNOS or iNOS at rostral ventrolateral medulla of rats. British Journal Of Pharmacology, 138(4), 584-593. doi: 10.1038/ sj.bjp.0705081.

26. Peng, J., Wang, Y., Wang, L., Yuan, W., Su, D., Ni, X. et al. (2009). Sympathoinhibitory mechanism of moxonidine: role of the inducible nitric oxide synthase in the rostral ventrolateral medulla. Cardiovascular Research, 84(2), 283-291. doi: 10.1093/ cvr/cvp202. 
27. Chan, S., Wang, L., Wang, S., \& Chan, J. (2001). Differential cardiovascular responses to blockade of nNOS or iNOS in rostral ventrolateral medulla of the rat. British Journal Of Pharmacology, 133(4), 606-614. doi: 10.1038/sj.bjp.0704105.

28. Kishi, T. \& Hirooka, Y. (2012). Oxidative stress in the brain causes hypertension via sympathoexcitation. Frontiers In Physiology, 3. doi: 10.3389/fphys.2012.00335.

29. Arnolda, L. (2002). Inducible nitric oxide synthase and cardiac dysfunction in salt-sensitive hypertension. Journal Of Hypertension, 20(12), 2355-2356. http://dx.doi.org/10.1097/00004872200212000-00011.

30. Tan, D. Y., Meng, S., Cason, G. W., \& Manning, R. D. (2000). Mechanisms of salt-sensitive hypertension: role of inducible nitric oxide synthase. Am J Physiol Regul Integr Comp Physiol,
279, R2297-R2303.

31. Loscalzo, J. (2001). Salt-Sensitive Hypertension and Inducible Nitric Oxide Synthase: Form-Function Dichotomy of a Coding Region Mutation, Mutatis Mutandis. Circ Res, 89, 292-294.

32. Tian, N., Gannon, A., Khalil, R., \& Manning, R. (2002). Mechanisms of salt-sensitive hypertension: role of renal medullary inducible nitric oxide synthase. American Journal Of Physiology - Regulatory, Integrative And Comparative Physiology, 284(2), R372-R379. doi: 10.1152/ajpregu.00509.2002.

33. McCloy, R. A., Rogers, S., Caldon, C. E., Lorca, T., Castro, A., \& Burgess, A. (2014) Partial inhibition of Cdk1 in G 2 phase overrides the SAC and decouples mitotic events. Cell Cycle, 13, 1400-1412. doi: 10.4161/cc.28401.

\section{Information about authors:}

Kolesnyk Yu. M., MD, PhD, DSci, Professor, Rector of Zaporizhzhia State Medical University, Head of the Department of Pathological Physiology, Zaporizhzhia State Medical University.

Kuzo N. V., Lecturer-intern, Department of Pathological Physiology, Zaporizhzhia State Medical University, E-mail: kuzo@zsmu.zp.ua. Hancheva O. V., MD, PhD, DSci, Professor, Department of Pathological Physiology, Zaporizhzhia State Medical University,

E-mail: gancheva@zsmu.zp.ua.

Abramov A. V., MD, PhD, DSci, Professor, Department of Pathological Physiology, Zaporizhzhia State Medical University.

Відомості про авторів:

Колесник Ю. М., д-р мед. наук, професор, ректор Запорізького державного медичного університету, зав. каф. патологічної фізіології, Запорізький державний медичний університет.

Кузьо Н. В., викладач-стажист каф. патологічної фізіології, Запорізький державний медичний університет,

E-mail:kuzo@zsmu.zp.ua.

Ганчева О. В., д-р мед. наук, професор каф. патологічної фізіології, Запорізький державний медичний університет, E-mail: gancheva@zsmu.zp.ua.

Абрамов А. В., д-р мед. наук, професор каф. патологічної фізіології, Запорізький державний медичний університет. Сведения об авторах:

Колесник Ю. М., д-р мед. наук, профессор, ректор Запорожского государственного медицинского университета, зав. каф. патологической физиологии, Запорожский государственный медицинский университет.

Кузьо Н. В., преподаватель-стажёр каф. патологической физиологии, Запорожский государственный медицинский университет, E-mail: kuzo@zsmu.zp.ua.

Ганчева О. В., д-р мед. наук, профессор каф. патологической физиологии, Запорожский государственный медицинский университет, E-mail: gancheva@zsmu.zp.ua.

Абрамов А. В., д-р мед. наук, профессор каф. патологической физиологии, Запорожский государственный медицинский университет. 